\title{
Effect of Pregnancy Process on Urinary System and Pelvic Floor and Nursing Approach
}

\section{Gebelik Sürecinin Üriner Sistem ve Pelvik Taban Üzerine Etkisi ve Hemşirelik Yaklaşımı}

\author{
(D) Nezihe KIZILKAYA BEJİ1, (1) Gülsüme SATIR², (D) Gülsen ÇAYIR²
}

${ }^{1}$ Biruni University Faculty of Health Sciences, Department of Nursing, İstanbul, Turkey

${ }^{2}$ Biruni University Faculty of Health Sciences, Department of Obstetrics, İstanbul, Turkey

\begin{abstract}
The pelvic floor is a structure composed of layers of muscles and fascia that support the opening of the vagina, rectum and urethra together with the abdominopelvic cavity. Pelvic floor includes structures effective in maintaining continence and sexual function. Although chronic cough, obesity, constipation, vaginal surgeries, trauma, race and advancing age are responsible for the deterioration of pelvic integrity with increased intraabdominal pressure; the most important reasons for this are pregnancy and giving birth. In this review, the effects of pregnancy on urinary system and pelvic floor were examined and discussed in the light of current literature.
\end{abstract}

Keywords: Pelvic floor, pelvic floor in pregnancy, pelvic floor disorders

\section{ÖZ}

Pelvis tabanı, abdominopelvik kaviteyle birlikte vajina, rektum ve üretranın dışa açıldığı noktaları destekleyen kas ve fasya tabakalarından oluşan bir yapıdır. Pelvik taban, kontinensin sağlanmasında ve cinsel fonksiyonda etkili olan yapıları içermektedir. Pelvik bütünlüğün bozulmasında intraabdominal basıncın artmasıyla seyreden; kronik öksürük, obezite, konstipasyon, vajinal ameliyatlar, travma, ırk ve ilerleyen yaş sorumlu tutulsa da en önemli sebepler gebelik ve doğumdur. Bu derlemede gebelik sürecinin üriner sistem ve pelvik taban üzerine etkileri incelenerek, güncel literatür doğrultusunda tartışıldı.

Anahtar Sözcükler: Pelvik taban, gebelikte pelvik taban, pelvik taban bozuklukları

\section{Introduction}

The pelvic floor consists of the muscle and fascia layers that support the openings of the vagina, rectum and urethra, along with the abdominopelvic cavity. It refers to all support structures that include pelvic organ support. The pelvic floor provides active support to the pelvic organs and muscles, while the fascia and ligaments provide passive support (1). The most important factor providing pelvic integrity is the pelvic muscles and endopelvic fascia (2). The endopelvic fascia is loose connective tissue that surrounds the pelvic organs, connecting them loosely to the muscles that support them and to the bone structures of the pelvis.
As is known, connective tissue is a type of biological tissue with a large extracellular matrix that supports, binds and protects organs. The extracellular matrix is a complex structure which is located between cells and support them. It contains structural proteins such as hyaluronic acid, chondroitin sulfate, collagen, elastin. The endopelvic fascia is a biological fabric that is three-dimensional and has the appearance of cobwebs (3). Collagen, elastin, adipose tissue, nerves, veins and lymph channels are composed of smooth muscle. Endopelvic fascia anchors and supports pelvic organs. In addition, it provides the movement needed for urine and gaita storage, parity, coitus and defecation. The uterosacral ligament, cardinal ligament and broad ligaments are thickening in the 
endopelvic fascia and are not actually ligaments. The role of the endopelvic fascia in supporting the bladder, urethra, vagina and other pelvic organs is great.

The term "pelvic diaphragm" is used for the levator ani muscle and the fascias that surround it. Pelvic diaphragm is composed of M. Levator Ani, M.Coccygeus and the fascias surrounding these muscles, and is the lowest part of the abdominal cavity. Rectum, urethra and vagina open into the the pelvic diaphragm. The pelvic diaphragm muscles are arranged as a " $U$ " the end of which is located at the front. The open part of $U$ is called the "urogenital hiatus". M. Levator Ani muscle makes up the bulk of the pelvic floor. It is composed of pubococcygeus and iliococcygeus muscles. The pubococcygeus muscle originates from the pubic bones and clings to the anococcygeal raphe (the anococcygeal raphe is the fibrous band between the anus and the upper surface of the coccyx) and the superior part of the coccyx. The most medial fibers of this muscle are close to the vagina. For this reason, it is called as the "pubovaginal muscle". The greater part of the muscle in the lateral is at the back of the anus and has two layers; the superficial muscle layer ends in the ligamentum anococcygeum. Contraction of this muscle causes elevation of the urethra, although it is not directly connected to the urethra. The deep layer (upper layer) fibers combine behind the rectum with the fibers of the opposite side to form a ring. These fibers are also called as the "puborectalis muscle" because of their close relationship with the rectum. The puborectalis muscle is adjacent to the vagina and clings to the vagina. M. Coccygeus is at the rear-top of the M. Levator Ani and has a triangular shape. It originates from the upper part of Spina Ischiadiaca and the sacrospinal ligament and ends at the last segment of the sacrum and the side of the os coccyx. If trauma and relaxation occur in the pelvic floor muscles, the pelvic floor opens, and if intraabdominal pressure increases, the vagina is left under low external pressure. Ligaments contribute to the adhesion of the vagina for a short time. If the muscles do not close the opening of the pelvic floor during this time, the level and location of the vagina will change.

Most of the muscle fibers found in M. Levator Ani are type 1 slow-contracting muscle fibers and provide continuous toning. The perianal and periurethral parts have type 2 fast-contracting muscle fibers. The continuous tonus provided by type 1 fibers closes the urogenital hiatus while the person is standing, reducing the load found on the passive connective tissue support of the pelvic viscera. Type 2 fibers respond quickly in moments of stress such as coughing, sneezing, and sudden intraabdominal pressure change (4). Iliococcygeus muscle has assumed a shelf-like barrier on the urogenital gap; it supports the uterus, vagina, bladder, and other pelvic organs, but also forms a muscle layer that avoids pelvic organs to prolapse from the urogenital range against increased intra-abdominal pressure. The pubococcygeus and puborectalis muscles surround the urethral and anal sphincters like a sling, helping to increase the intrinsic smooth muscle tone and provide tonic-phasic pressures. When intra-abdominal pressure increases, these muscles maintain continence by increasing the urethral and anal sphincter pressure (5).
For urinary control, it is necessary to store urine at low pressure and sufficient amount in the bladder, and a healthy bladder neck, an active distal urethral sphincter (sphincter formed by skeletal muscle) and strong pelvic floor muscles are necessary. The inability of the bladder to respond to the excess amount of urine with increasing pressure, in other words, impaired compliance is an important part of the incontinence mechanism. The bladder contracts together with the voluntary sphincter, which is made of skeletal muscle, before intraabdominal pressure increases, maintaining urinary control. In women, the bladder neck is weak compared to men and may be easily inadequate. The most important part of the urinary control mechanism is the voluntary sphincter and the active force in closing the bladder outlet. Pelvic floor muscles provide anatomical support. When intraabdominal pressure increases, the urethra becomes trapped between pressure and intact pelvic floor tissue. If the pelvic floor muscles weaken, this compression is insufficient and results in incontinence (6).

Although chronic cough, obesity, chronic constipation, diseases such as COPD, vaginal surgeries, trauma, race and advancing age are responsible for the deterioration of pelvic integrity; the most important reasons for this are pregnancy and giving birth $(2,7)$. Pregnancy causes differences in the structure of all organs, but the data about how it affects the pelvic floor are very limited. It is not clear whether pregnancy or childbirth contributes more to pelvic floor disorders, and studies supported by numerical data are few $(8,9)$.

Pelvic floor muscle power decreases beginning from $20^{\text {th }}$ gestation week to postpartum 6th week. Changes in local tissues caused by the effect of relaxin and reproductive hormones lead to negative effects on pelvic floor muscles. The hormone relaxin softens the connective tissue in the pelvic floor to allow it to prepare for birth (10). Hormonal changes in pregnancy cause physiological changes in all organs. The placement of the fetus in the pelvis and the effect of hormonal differences on the physiology of the pelvis are influential on pelvic floor and pelvic floor support (2).

In pregnant women, the tensile strength of fascias is found to be less than in non-pregnant women. As the uterus grows during pregnancy, intraabdominal pressure increases and the pelvic organs are pushed downwards. This condition exposes the pelvic floor muscles to constant stress and strain and negatively affects pelvic support throughout pregnancy. In the early stages of pregnancy, when viewed with perineal ultrasound, it is observed that the pelvic floor is displaced in the downward direction. It is stated that the contractions of the pelvic floor muscles decrease at a certain rate, the mobility of the bladder and urethra is increased, and that this mobility increase occurs more in the late gestational period (8).

The effects of pregnancy on the urinary system;

- Renal pelvises are disproportionately enlarged. The right renal pelvis is measured in the range of $5 \mathrm{~mm}(5-25)$ and the left renal pelvis is measured in the range of $5 \mathrm{~mm}(3-8)(11)$. 
- Due to the right rotation of the uterus and the left sigmoid colon having a cushion effect on the left urethra, the right urethra is more dilated than the left (11).

- The fact that urethral dilation is below the pelvic girdle shows the mechanical effect of the growing uterus. This dilation is seen in the $8^{\text {th }}$ week and reaches the highest level in the $2^{\text {nd }}$ trimester, all of which are not fully explained by mechanical factor and hormonal factors are thought to have an effect (12).

- Ureters of term pregnant women hold $200 \mathrm{~mL}$ more volume compared with women without pregnancy.

- Urethral dilation recedes until the $3^{\text {rd }}$ postpartum month (11).

- The functional length of the urethra during pregnancy reaches from $30 \mathrm{~mm}$ to maximum $35 \mathrm{~mm}$ in the third trimester, decreasing to $28 \mathrm{~mm}$ in the postpartum period. This occurs when the bladder shifts upwards and forwards (12).

- Increased blood volume causes increased blood flow to the pelvic organs (11).

- Increase in hormone production leads to relaxation of the musculoskeletal system in the whole body, especially the pelvis (11).

- Blood and edema in the pelvic diaphragm also contribute to the relaxation of this layer (11).

- In the middle of pregnancy, bladder capacity reaches from 410 $\mathrm{mL}$ to $460 \mathrm{~mL}$. But in the late third trimester it falls again to $272 \mathrm{~mL}$ due to relaxation of the uterus sub-segments and the fetal head being engaged in the pelvis (12).

Increase in bladder and urethra pressure in pregnancy is 2-3 times more than intraabdominal pressure and thus urination is provided. Another mechanism that explains the incidence of stress urinary incontinence in pregnancy needs to be effective. The looseness of pelvic muscles and connective tissue is one of the causes of stress incontinence. Despite increased bladder pressure in women who experience stress incontinence during pregnancy, urethral pressure is insufficient (11). Pregnancy and especially vaginal delivery, negatively affect bladder neck support and its drop by valsalva maneuver, but this has not been correlated with incontinence.

Causes of pelvic floor dysfunction in pregnancy; baby's birth weight, body mass index (BMI), smoking, genetic predisposition, age, intraabdominal pressure and nutrition (13). Hormones throughout pregnancy influence the biochemical composition of the extracellular matrix and the hydration of pelvic floor tissue. It causes the diameter of the collagen fibers and the convoluted structure of the collagen fibrils to change. Such effects in pregnancy can affect viscoelastic features in the vaginal wall, pubovisceral muscles, and the perianal region. Changes in collagen cause increased mobility of the bladder neck and stress incontinence. As the collagen component of connective tissue contributes to the structural support of the neck of the bladder, abnormalities in collagen can increase the risk of incontinence. As the amount of collagen is reduced in pregnancy, the tension property of connective tissue is also reduced (14).

Pelvic floor disorders including pelvic organ prolapse, urinary system/defecation dysfunctions, sexual dysfunction and pelvic pain can be seen in pregnancy.

Pelvic organ prolapse is the prolapse of the anterior and/or posterior walls of the vagina, uterus (cervix) and the vaginal vault downwards in patients with a history of hysterectomy. This finding is present with symptoms and is usually seen at hymen level or below levels. It is a major health problem in developed and developing countries. There is little data on pelvic organ prolapse in pregnancy. But the level of prolapse is thought to increase in pregnancy.

Pelvic organ prolapse is the prolapse of the anterior and/or posterior walls of the vagina, uterus (cervix) and the vaginal vault downwards in patients with a history of hysterectomy. This finding is present with symptoms and is usually seen at hymen level or below this level. It is a major health problem in developed and developing countries. There is little data on pelvic organ prolapse in pregnancy. But the level of prolapse is thought to increase in pregnancy.

There are studies that show that the third trimester of pregnancy and the postpartum period cause prolapse more than the first trimester. This means that pregnancy weakens pelvic support regardless of birth. The effects of hormonal change in pregnancy on collagen structure, growth of the uterus throughout pregnancy, increased tension of pelvic floor muscles weakening the uterus, reduce pelvic floor support. As the amount of collagen in the endopelvic fascia decreases; pelvic floor support is also reported to decrease and pelvic support injury occurs before birth (9).

During pregnancy, the first and most affected area of prolapse in pregnant women is the "Aa" point according to the POP-Q (Pelvic Organ Prolapse-Quantification) classification system $(2,15,16)$. Pregnant nullipars and non-pregnant nullipars were compared and stage- 2 was detected in $47.6 \%$ of pregnant women, whereas no further prolapse than stage-1 was reported in non-pregnant women. In this context nullipar pregnancy in women is related to more advanced pelvic organ prolapse (2).

There are several risk factors for urinary incontinence (UI), including age, birth, menopause, and smoking. Stress urinary incontinence (SUI) is defined by the International Continence Society (ICS) as urinary incontinence from the urethra along with increased intrabdominal pressure during physical activity (6). Prevalence of SUI in gestation has been found between $18.6 \%$ and $75 \%(17,18)$. Pregnancy is one of the main risk factors for SUI development. Pregnancy is be associated with a decrease in pelvic floor muscle strength, which may lead to 
a decrease in the strength, supporting function and sphincter function of the pelvic floor muscle. However, the mechanism of pregnancy-related SUI is not fully understood. Huebner stated that UI prevalence increased in the second half of pregnancy in the study conducted with 411 pregnant women. Milsom's study found that the prevalence of UI increased in pregnancy (especially in the second trimester) and then gradually decreased in the first months of the first year after birth (19).

The pelvic floor muscle plays a complementary role in maintaining the continence mechanism by actively supporting the pelvic organs and closing the urethral sphincter during contraction. When coughing, sneezing, laughing, or moving, intra-abdominal pressure increases and this pressure is transmitted to the bladder. When the pressure in the bladder is greater than the urethral closure pressure along with the weakness of the urethral sphincter, this results in incontinence or SUI (17).

However, SUI seen in women during pregnancy can be prevented and improved with pelvic floor muscle exercise (PFME). PFME aims to increase pelvic floor muscle (PFM) strength to support the bladder, ureter and urethra; increase the effectiveness of sphincteric function of the urethra during exertion; and improve the continence mechanism after proper contraction of the pelvic floor.

Oliveira et al. reported that PFME led to a significant increase in PFM pressure and force during pregnancy. PFME is therefore recommended as the first intervention that prevents and improves the symptoms of pregnancy and postpartum SUI before considering other interventions.

In pregnancy, difficulty in micturation is quite common. During early gestation (up to $12^{\text {nd }}-14^{\text {th }}$ gestation weeks), the cause of urinary retention is the retrovert uterus. This creates mechanical pressure on the bladder neck and urethra. Urinary retention may develop as a result of the uterus compressing the bladder during late gestation (11).

As a result of frequent urination (frequency) in pregnancy, The increase in plasma volume during early pregnancy and the pressure of expanding uterus on the bladder are reported as the causes of frequent urination in pregnancy. A study performed in women in the $32^{\text {nd }}$ gestation week suggested that the expanding uterus caused upward displacement of the bladder, resulting in frequent urination due to pressure on the bladder (11).

Pregnancy and childbirth also cause defecation disorders. Anal incontinence occurs in $1.3 \% 16 \%$ of pregnant womens (20). Coordination integrity between the neuromuscular body of the colon and rectum and the anal sphincter plays an important role in maintaining defecation control and continence.

Innervation of internal anal sphincter, transmission of impulse to circular muscle layer and enteric nervous system of rectum, close relationship between external anal sphincter and pelvic floor muscles, especially puborectalis muscle and the coordination of puborectalis muscle, longitudinal muscle of rectum and anal canal muscles play important role in this coordination integrity (2). In addition, another important factor in maintaining defecation control and continence is the increase of anorectal angle as a result of contraction of the puborectal muscle, which allows for greater retention of feces (2).

Ischiocavernosus, bulbocavernosus, and levator ani muscles and pelvic floor muscles which are effective on sexual function, pull the rectum, vagina and anterior part of urethra towards the pubic bone and close the lumen during vaginal penetration and orgasm. The literature states that strong pelvic floor muscles, especially the ischiocavernosus muscle, have an important role in achieving genital arousal and orgasm (21). The strong pelvic muscles provide strong lubrication, arousal and an increase in orgasm. Sexual pain disorders are seen if excessive tonus increase occurs in pelvic muscles. Vaginal sensitivity, decrease in orgasm intensity and UI during sexual intercourse are seen if hypotonia occurs (22).

Pelvic pain is pain felt in the lower quadrant of the abdomen and pelvis (23). A fifth of women in pregnancy experience pelvic pain (15). The etiology of pelvic pain seen in pregnancy is not fully understood (24).

Nurses should plan training and provide information for preventing and protecting pelvic floor dysfunction for pregnant women 13. A comprehensive anamnesis should be taken to determine the factors that may cause risk in pregnant women. The woman's health behaviors during pregnancy affect her pregnancy, birth and the health of the newborn 25. Pregnant women should be supported to gain healthy lifestyle behaviors (controlling all behaviors that may affect the health of the individual, choosing and regulating behaviors appropriate to the health condition while performing daily life activities with the ability to make decisions and making these behaviors habitually) (26). Pregnant women should be given training on PFME (27). In the literature, there are studies that report that UI can be prevented in pregnant women who perform PFME in the last trimester and after birth (28). PFME increases PFM strenght and reduces the risk of pelvic organ prolapse. It also prevents hemorrhoids and increases excretory control and orgasm $(10,29)$. Furthermore, pregnant women should be informed about taking care of weight gain during pregnancy, consuming fibrous foods to prevent constipation, consuming enough fluids, not lifting heavy, not smoking, avoiding valsalva maneuvers as much as possible $(13,30)$.

\section{Conclusion}

As a result, pregnancy causes changes in the pelvic floor and urinary system. Urinary incontinence, pelvic organ prolapse, fecal incontinence and pelvic pain are caused by the inability of the pelvic floor. Training should be given to pregnant women in order to maintain the function of the pelvic floor. 


\section{Ethics}

Peer-review: Eternally peer reviewed.

\section{Authorship Contributions}

Concept: N.K.B., G.S., Design: N.K.B., G.S., G.Ç., Analysis or Interpretation: N.K.B., G.S., G.Ç., Literature Search: N.K.B., G.S., G.Ç., Writing: G.S.

Conflict of Interest: No conflict of interest was declared by the authors.

Financial Disclosure: The authors declared that this study received no financial support.

\section{References}

1. Sarıcı DY, Boran AB. Üriner İnkontinans Tedavisinde Pelvik Taban Egzersizleri Nöromodülasyon-biofeedback İçin Evde Egzersiz Eğitim Uygulaması Kısa Dönem Sonuçları. Uzmanlık Tezi. İstanbul, 2009;45 .

2. Kumtepe Y. Pelvis tabanı, gebelik ve doğum. Yalçın Ö (Editör). Temel Ürojinekoloji. İstanbul: Nobel Tip Kitabevleri; 2009;61-5.

3. 3Üçgül İ, Aras S, Elibüyük U. Ekstraselüler matris yapısı ve görevleri. Uludağ University Journal of The Faculty of Engineering, 2018;23:295-310.

4. Dere F, Karın duvarları ve pelvis, "Anatomi” 2. Baskı, Adana, s, 1990, 166-204.

5. Aydın ÇEN. Gebelikte başlayan pelvik taban bozukluğu sıklığının belirlenmesi ve doğum sonrası 6. Ayda sebat eden olguların özelliklerinin öngörülmesi, Ankara Üniversitesi Tip Fakültesi, Doğum ve Kadın Hastalıkları Anabilim Dalı, Tıpta Uzmanlık Tezi. 2016;21-2.

6. Demircan N, Özmen Ü, Köktürk F, Küçük H, Ata Ş, Harma M, Arıkan, III. What are the probable predictors of urinary incontinence during pregnancy. Peer J 2016;4:e2283.

7. Sancak, P. Pelvik organ prolapsusu ve/veya inkontinansı olan kadınlarda cinsel disfonksiyon ve pelvik organ prolapsusu/idrar inkontinans cinsel fonksiyon sorgulaması (PISQ-12) formunun validasyonu. TC Sağlık Bakanlığı Zeynep Kamil Kadın ve Çocuk Hastalıkları Eğitim ve Araştırma Hastanesi Kadın Hastalıkları ve Doğum Kliniği Uzmanlık Tezi 5. 2008.

8. Akbayrak T, Kaya S, Tedavi F. Gebelik ve egzersiz. Hacettepe Üniversitesi Sağlık Bilimleri Fakültesi, Fizik Tedavi Ve Rehabilitasyon Bölümü Klasmat Matbaası, Ankara. 2008.

9. Bozkurt M, Yumru AE, Şahin L. Pelvic floor dysfunction, and effects of pregnancy and mode of delivery on pelvic floor. Taiwanese Journal of Obstetrics and Gynecology 2014;53:4,452-8.

10. Dönmez S, Kavlak O. Gebelikte pelvik taban kas egzersizi. Balıkesir Sağlık Bilimleri Dergisi,2014; 3:1,45-49.

11. Dinç A. Üriner İnkontinans Şikâyeti Olan Gebelerde Gebelik ve Postpartum Dönemde Uygulanan Pelvik Taban Kas Egzersizlerinin Bu Şikâyetin Giderilmesindeki Etkinliği”, İstanbul Üniversitesi Sağlık Bilimleri Enstitüsü, Doğum ve Kadın Hastalıkları Hemşireliği Anabilim Dalı, Doktora Tezi. 2004.5-6
12. Gollin YG. Gebelik sırasında ve puerperium'da idrar yollarında görülen değişiklikler. ürojinekoloji ve pelvik rekonstrüktif cerrahi temel bilgiler, Çev. Önay Yalçın. Mcgraw-Hill, Türkiye Klinikleri 2007;203-8.

13. Kahyaoğlu Süt H. Gebelik ve doğumun pelvik taban yetersizlikleri üzerine etkisi: önlenmesi ve korunmada hemşirenin rolü. Gümüşhane Üniversitesi Sağlık Bilimleri Dergisi 2015;4:292-304.

14. Abrams P, Cardozo L, Wagg A, Wein A. Incontınence, 6 th Internatıonal Consultatıon on Incontınence, Tokyo 2016;378-9.

15. Turan İ. (2016). Pelvik taban cerrahisinin seksüel fonksiyon ve yaşam kalitesi üzerine etkisinin incelenmesi, Pamukkale Üniversitesi Tıp Fakültesi, Doğum ve Kadın Hastalıkları Anabilim Dalı, Tıpta Uzmanlık Tezi. 17-20.

16. Liddle SD, Pennick V. Interventions for preventing and treating low-back and pelvic pain during pregnancy. Cochrane Database of Systematic Reviews 2015;9.

17. Sangsawang B. Risk factors for the development of stress urinary incontinence during pregnancy in primigravidae: a review of the literature. European Journal of Obstetrics \& Gynecology and Reproductive Biology 2014;178:27-34.

18. Luo D, Chen L, Yu X, Ma L, Chen W, Zhou N, Cai W. Differences in urinary incontinence symptoms and pelvic floor structure changes during pregnancy between nulliparous and multiparous women. PeerJ 2017;5:e3615.

19. Milsom I, Altman D, Cartwright R, Lapitan MC, Nelson R, Sjöström S, et al. Epidemiology of urinary incontinence (UI) and other lower urinary tract symptoms (LUTS), pelvic organ prolapse (POP) and anal incontinence (AI). In: Abrams P, Cardozo L, Wagg A, Wein A editor(s). Incontinence: 6th International Consultation on Incontinence, Tokyo, September 2016. 6th Edition. Vol. 1, Bristol (UK): International Continence Society (ICS) and International Consultation on Urological Diseases (ICUD) 2017:1-141.

20. Rogers RG, Ninivaggio C, Gallagher K, Border AN, Qualls C, Leeman LM. Pelvic floor symptoms and quality of life changes during first pregnancy: a prospective cohort study. International urogynecology journal 2017;28:1701-7.

21. Ceylan Çelik F. Pelvik taban elekromyografik aktivite cevabı ve abdominal kas kuvvetinin, kadın cinsel fonksiyonu ile ilişkisinin değerlendirilmesi, 2013.

22. Polat B. Pelvik taban kas zayıflı̆̆ olan kadınlarda pelvik taban eğitiminin cinsel fonksiyon ve yaşam kalitesi üzerine etkisi. MS thesis. Sağlık Bilimleri Enstitüsü, 2017.

23. 23.Demir F. Kronik pelvik ağrıda jinekolojik, ürolojik, psikiyatrik etkenlerin araştırılması: Diagnostik laparoskopinin kronik pelvik ağrıdaki yeri. Diss. SDÜ Tıp Fakültesi, 2006.

24. Hall H, Cramer H, Sundberg T, Ward L, Adams J, Moore C, Lauche R. The effectiveness of complementary manual therapies for pregnancy-related back and pelvic pain: A systematic review with meta-analysis. Medicine 2016;95:38. 
25. Ural A. Gestasyonel diabetes mellitus ve sağlıklı yaşam biçimi davranışları. Düzce Üniversitesi Sağlık Bilimleri Enstitüsü Dergisi 2016;6:120-2.

26. Kostak MA, Kurt S, Süt N, Akarsu Ö, Ergül GD. Hemşirelik ve sınıf öğretmenliği öğrencilerinin sağlıklı yaşam biçimi davranışları. TAF Preventive Medicine Bulletin 2014;13:3.

27. Aktas D, Sahin E, İlknur MG. Kadın sağlığını etkileyen, sık görülen bazı jinekolojik problemler ve hemşirelik yaklaşımları. Ankara Sağlık Bilimleri Dergisi 2012;1:37-53.

28. Woodley SJ, Boyle R, Cody JD, Markved S, Hay Smith EJC. Doğum öncesi ve doğum sonrası kadınlarda idrar ve dışkı idrar kaçırmalarının önlenmesi ve tedavisi için pelvik taban kas eğitimi. Sistematik incelemelerin cochrane veri tabanı 2017;12.

29. Rivalta M, Sighinolfi M.C, Micali S, De Stefani S, Bianchi G. Sexual function and quality of life in women with urinary incontinence treated by a complete pelvic floor rehabilitation program (biofeedback, functional electrical stimulation, pelvic floor muscles exercises, and vaginal cones). The journal of sexual medicine 2010;7:1200-8.

30. Demir R, Taşpınar A. Kadın sağlığının korunmasında kegel egzersizlerinin önemi ve ebelik yaklaşımı. Ege Üniversitesi Hemşirelik Fakültesi Dergisi 2018;34:77-88. 